\title{
Production RAW Material Inventory Control Information System at PT. SIIX EMS Indonesia
}

\author{
Tukino ${ }^{1}$ \\ Information Systems Study Program \\ School of Engineering and Computer Science \\ Universitas Buana Perjuangan Karawang \\ tukino@ubpkarawang.ac.id
}

\author{
Shofa Shofia Hilabi ${ }^{2}$ \\ Information Systems Study Program \\ School of Engineering and Computer Science \\ Universitas Buana Perjuangan Karawang \\ shofa.hilabi@ubpkarawang.ac.id
}

\author{
Heri Romadhon \\ Information Systems Study Program \\ School of Engineering and Computer Science \\ Universitas Buana Perjuangan Karawang \\ si15.Heri.romadhon@ubpkarawang.ac.id
}

\begin{abstract}
Application of web-based raw material inventory control information system with a bill of materials (BOM) using the PHP and MySQL programming language as a database, and using the SDLC livestock device engineering method with stages of planning, design, implementation, and testing. I create a recording application that provides information about the availability of raw material reducing the error in calculating the amount of raw material based on the bill of material. With this application, it can help to purchase in determining the number of raw materials needed for production based on the master bill of material data.
\end{abstract}

Keywords - Inventory, bill of material, information system.

\section{INTRODUCTION}

This The production process is the core activity of a manufacturing company. In the production process, they require a company to produce a quality product following consumer desires. To conduct production activities, good raw materials must be available and following the company's production needs. Therefore, determining the raw material inventory and is a very important activity in a production process.

Planning for the right raw material inventory is very supportive in the smooth production process. The smooth production process is very important for the company because it is very influential on the level of sales and profits got by the company. Factors that influence the smooth production process are the availability of raw materials that will be processed in the production process.

If raw material inventory is not available with the required amount or raw material is late until the company, then it will have a bad influence on the company that is affecting the company's profits, this is because of costs incurred for the company running out of inventory which results in lost opportunities benefit because consumer demand cannot be served and the production process is interrupted.

In the research the author will conduct that is research on controlling raw materials in electronic products in the SIIX EMS (Electronic Manufacturing Services) company. The main raw materials for the electronic products are PCB (printed circuit board), capacitors, resistors, LEDs (Liquid Crystal Display) and diodes. Description of raw material into finished goods presented by PT. SIPX Ems Indonesia in the form of $(\mathrm{BOM})$ bill of materials is a special table that shows how raw material changes into finished products. In the bill of material will show each product has a composition of any raw material and the size or amount needed to make one finished product.

With the problems that occur in controlling the residual and the need for the use of raw material production, the author intends to analyze the system design Information System Inventory Control Material Production Row in P.T. SIIX EMS Indonesia.

\section{THEORETICAL BASIS}

\section{A. Information Systems}

In the research process information system design requires an understanding of information systems, there are several opinions according to experts as follows:

Information Systems are systems that can be defined by collecting, processing, storing, analyzing, distributing, information for specific purposes. Like other systems, an information system consists of inputs (data, instructions) and outputs (reports, calculations) " [3]

Information Systems is a system within an organization that meets the needs of daily transactions that support the organization's operational functions that are managerial with the strategic activities of an organization to be able to provide certain external parties with the reports needed "[4].

In simple information systems of understanding above have in common that the information system will produce a report, meaning a process that produces a report or data.

\section{B. System Analysis}

In a study a researcher must find the existing problems and solve those problems with certain methods of the system running and aims to find out all the problems that occur and facilitate in carrying out the next stage through analysis that has been made, according to experts the analysis of the system can be defined as the following:

Argues that system analysis is a process of reviewing an information system and dividing it into its constituent components for later research so that known problems and needs that will arise so that it can be reported in full and proposed improvements to the system " [5].

Analysis of the system is a method for finding solutions to existing system problems by grouping existing 
components into smaller components so that the solutions found by system requirements [6].

From the above definition, quotations have in common in the understanding that analysis is the process of solving the problem means that the existing problems will be solved by a particular method to get a solution to the problem.

\section{Waterfall}

Someone who conducts research certainly has a method of solving problems in a study, one of which is the waterfall method of various methods that will also be used by the author. This method is a classic method but is still often used in research methods, experts are precise about this method as follows:

Waterfall is one method of developing information systems that are systematic and sequential, meaning that each stage in this method is carried out sequentially and continuously [7].

The waterfall model as one of the basic theories and as required to be studied in the context of the software life cycle, is a life cycle that consists of starting the life phase of the software before it occurs until post-production [8]

The description of the waterfall method defined by the experts above can be drawn in outline by the authors of the method which is systematically structured from the phase before it starts to the phase after the information system starts.

The stages of the waterfall method can be seen in the figure below according to [9].

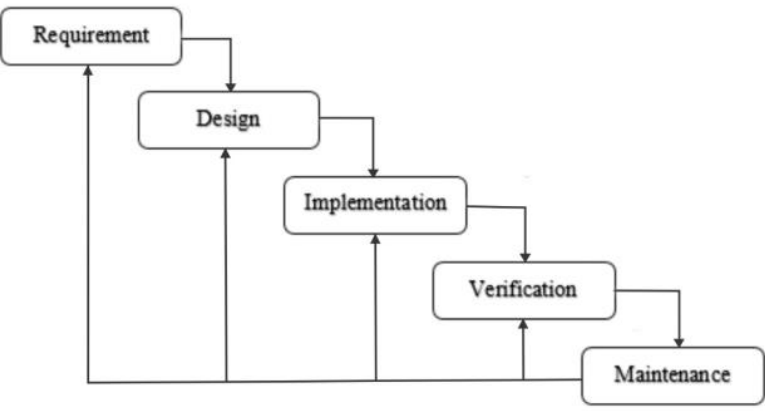

Fig. 1. Waterfall Model [9].

\section{Raw Material Inventory}

In a company, every operational manager is required to be able to manage and hold inventory to create effectiveness and efficiency.

Inventory of raw materials is Inventory of raw materials has an important position in the company because the supply of raw materials is a very large influence on the smooth production process [13].

Inventories of raw materials are inventories are stored materials or goods that will be used to fulfill certain purposes, for example, for use in the production or assembly process, for resale, or parts of an equipment or machine". From the above understanding, it can be understood that raw materials are raw materials, semi-finished materials, and materials that will be processed in the production process to become a finished product [14].

\section{RESEARCH METHODS}

In this study, there is further research that contains the stages. This framework is the steps or stages that will be carried out by researchers in the settlement that will be discussed. Is a flow cart picture.

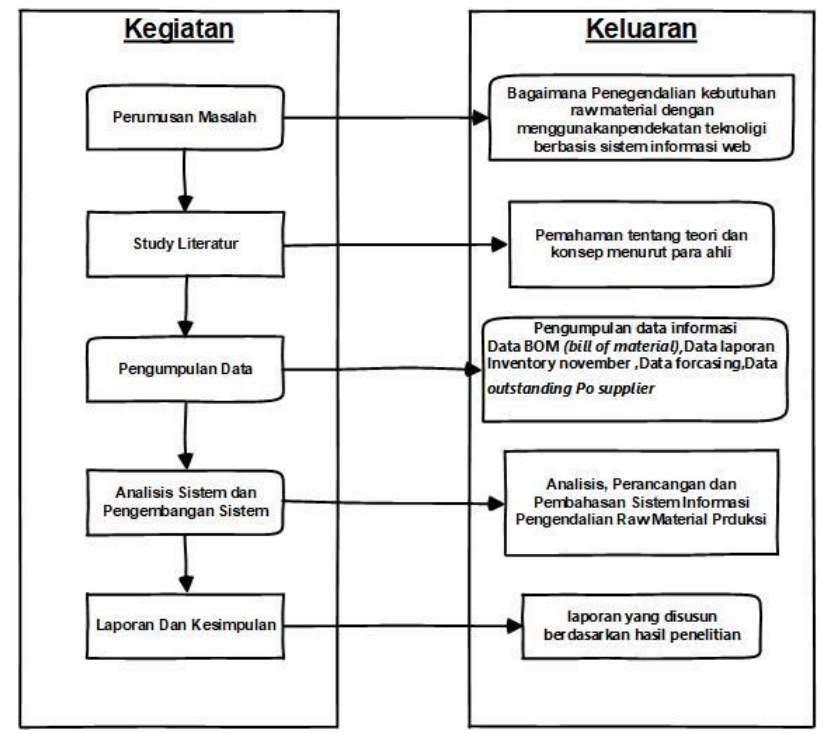

Fig. 2. Research Framework

\section{RESULT AND DISCUSSION}

\section{A. Use Case System Diagram}

To illustrate the system activities that will be made, the author uses modeling with use case diagrams. The use case diagram is used to find out what functions existing in the system and anyone who may use these functions. The use case diagram for the following raw material inventory control systems:

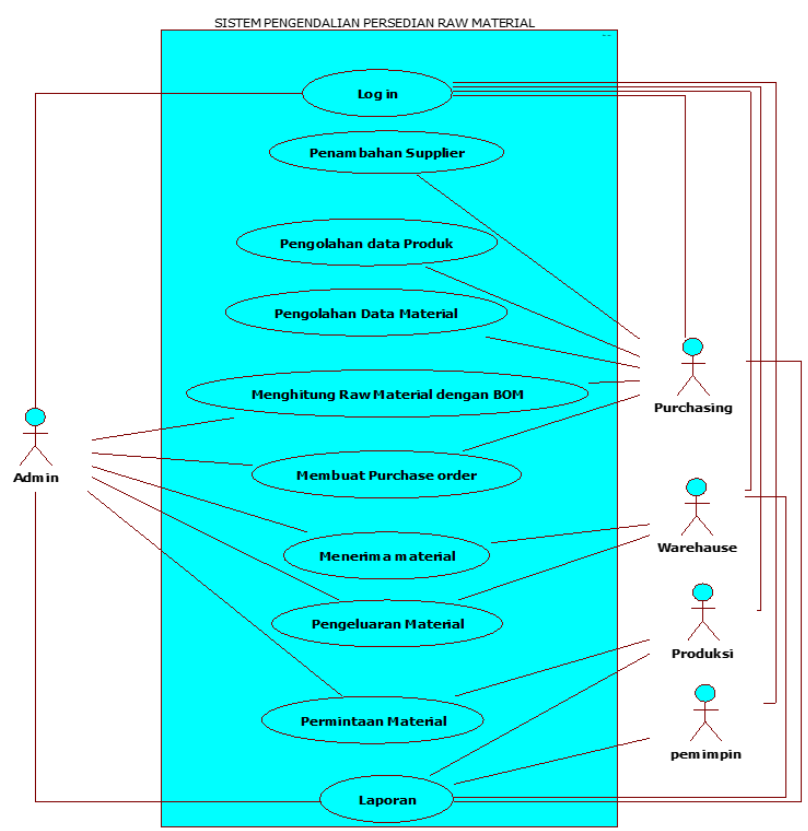

Fig. 3. Use case diagram of raw material inventory control system 


\section{B. Class Diagram}

After the use case diagram, the writer makes a class diagram aimed at a container that describes the structure of objects in the system formed from the relationships between classes. The class diagram is:

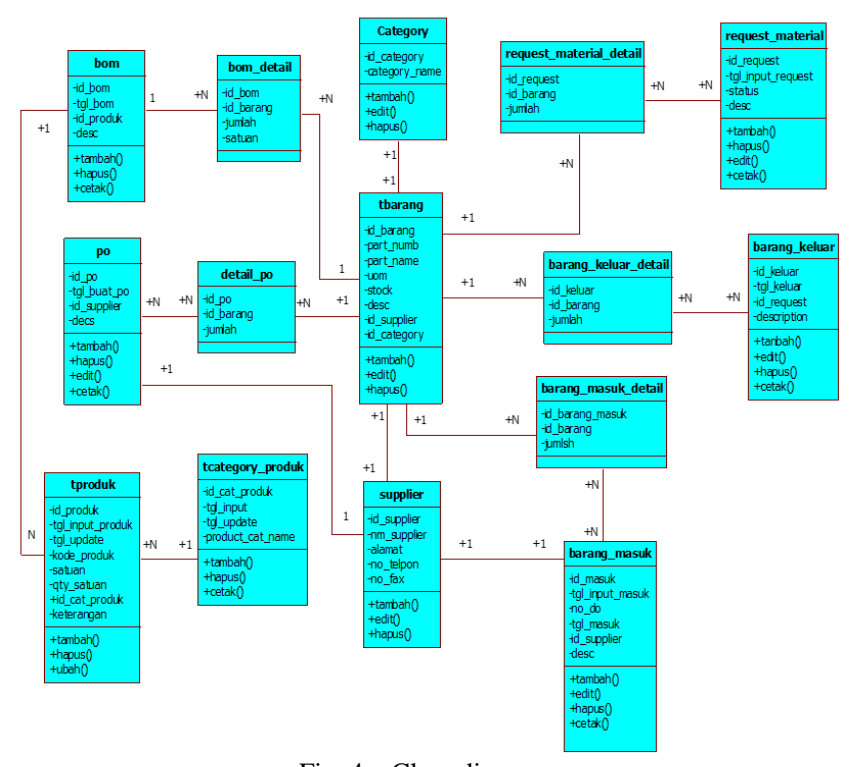

Fig. 4. Class diagram

C. Implementation

1. Login page

The login page is the start page that appears when opening a user page (backend). The function of the page is for the user to enter the main web page application:

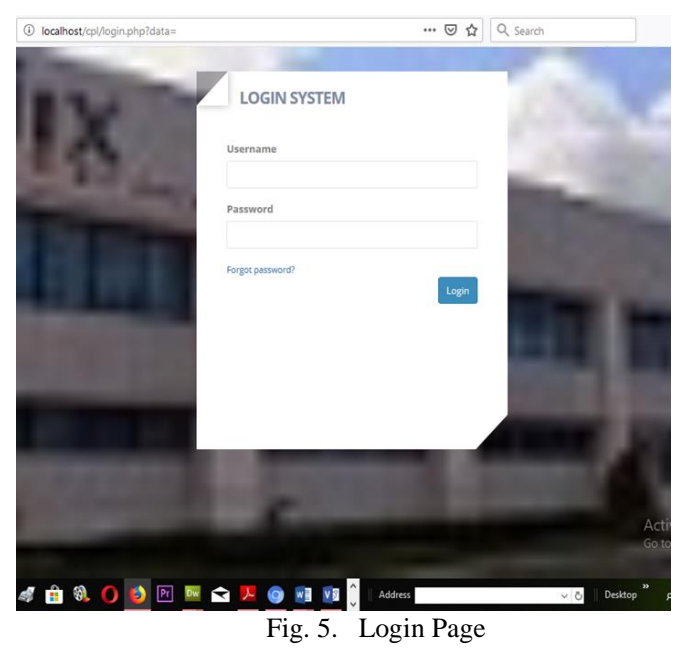

1. Main page

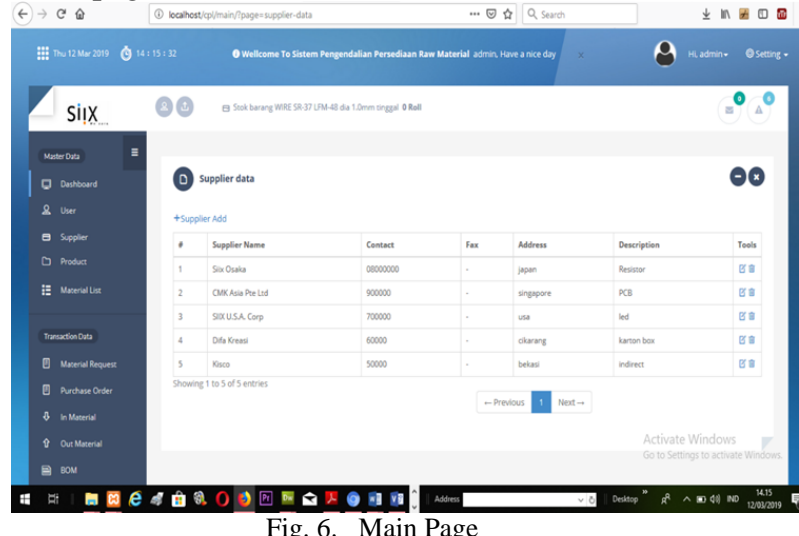

\section{CONCLUSION}

Based on the analysis that has been done, the authors can conclude that consumer satisfaction is a major factor in winning increasingly fierce industry competition. Consumer satisfaction can be achieved in several ways including quality products, competitive prices, and timely delivery.

Therefore, a company needs to pay attention to the control and planning of raw material inventory (Raw Material) to achieve the effectiveness and efficiency of data processing to maintain smooth production and increase customer satisfaction. To be able to optimize the inventory function, companies must make plans in the procurement of raw materials. The planning must be following the production needs for each boast with the existence of a raw material control system that has been made, is expected to facilitate the admin in conducting raw material relations, search for data to make reports, so that the creation of better jobs. As for the discussion of the previous chapters conclusions can be drawn as follows:

1. The raw material control system at PT. Six Ems Indonesia, especially for calculating raw material production needs, still use excel files and different storage databases. This causes the operational processes that are not yet maximized.

2. Calculation of raw material requirements in the application using the bill of material multiplication.

3. In the application, a form is provided for request input or forecasts from the customer and then automatically calculates the raw material production requirements.

\section{REFERENCES}

[1] Swastika, I.P.A. \& Putra, I.G.L.A.R. 2016. Audit Sistem Informasi dan Tata Kelola Teknologi Informasi. Yogyakarta: CV. Andi Offset.

[2] Ahmad, Rohani. 2010. Pengelolaan Pembelajaran. Jakarta: PT Rineka Cipta.

[3] Sutarman. 2012. Buku Pengantar Teknologi Informasi. Jakarta: Bumi Aksara.

[4] Tata Sutabri. 2012. Konsep Sistem Informasi. Andi: Yogyakarta.

[5] Wahana, Komputer. 2010. Shourtcourse SQL Server 2008 Express. Yogyakarta: Andi Offset.

[6] Whitten \& Jeffery, Bentley. 2009. System Analysis and Design Methods. New York: The mcGraw-Hill Companies, Inc. 
[7] Nasution, Ruslan Efendi. 2012. Implementasi Sms Gateway In The Development Web Based Information System Schedule Seminar Tesis. Lampung : Unila.

[8] Rizky, Soetam. 2011. Konsep Dasar Rekayasa Perangkat Lunak. Jakarta: Prestasi Pustaka.

[9] Roger, S \& Pressman, Ph.D. 2012. Rekayasa Perangkat Lunak Yogyakarta: Andi.

[10] Budiman, Agustiar. 2012. Pengujian Perangkat Lunak denganMetode Black Box Pada Proses Pra Registrasi UserVia Website. Makalah Hal:4.
[11] Al-Bahra Bin Ladjamudin. 2013. Analisis dan Desain Sistem Informasi. Yogyakarta : Graha Ilmu.

[12] Shalahuddin, M. 2013. Rekayasa Perangkat Lunak Terstruktur Dan Berorientasi Objek. Bandung: Bandung.

[13] Rangkuti F, (2007). Manajemen Persediaan "Aplikasi di Bidang Bisinis”. Jakarta : Raja Grafindo Persada

[14] Eddy, Herjanto. (2007. Manajeman Produksi dan Operasi . Jakarta :PT. Gramedia Wiarsarana Indonesia.

[15] Baridwan, Zaki. 2011. Intermediate Accounting Edisi 8. Yogyakarta : BPFE.

[16] Assauri, Sofjan. 2008. Majemen Produksi dan Operasi. Jakarta 